\title{
Pelvis Cancer pT4b TNM Finding v8
}

National Cancer Institute

\section{Source}

National Cancer Institute. Pelvis Cancer pT 4b TNM Finding v8. NCI Thesaurus. Code C136605.

Pelvis cancer with tumor encasement of external iliac vessels or presence of gross tumor thrombus in major pelvic vessels. (from AJCC 8th Ed.) 